The Possibilities of Agriculture

Author(s): P. Propotkin

Source: All Ireland Review, Vol. 3, No. 2 (Mar. 15, 1902), p. 28

Published by: All Ireland Review

Stable URL: http://www.jstor.org/stable/20545925

Accessed: 20-06-2016 14:12 UTC

Your use of the JSTOR archive indicates your acceptance of the Terms \& Conditions of Use, available at

http://about.jstor.org/terms

JSTOR is a not-for-profit service that helps scholars, researchers, and students discover, use, and build upon a wide range of content in a trusted

digital archive. We use information technology and tools to increase productivity and facilitate new forms of scholarship. For more information about JSTOR, please contact support@jstor.org.

All Ireland Review is collaborating with JSTOR to digitize, preserve and extend access to All Ireland Review 
above the Blackwater, and later on as the country became settled in plantation times a village grew up in the shelter of the Fort, which was a very necessary protection, as however careful of their stock the settlers might be "the wolf and the wood kerne had their share." In 1641 it was taken in very dramatic fashion by Sir Phelim O'Neill, and until the close of the rebellion, was the impregnable stronghold and rallying place of the Ulster Irish. Stout old Sir Teige O'Regan, held it for James II., until he was forced to capitulate to the Duke of Schomberg. Meantime the village in shadow of the Fort had been created a borough and was the property of the Charlemont family, and it was on the nomination of James, first Earl of Charlemont, and Commander-inChief of the volunteers, that Ireland's patriot statesman, Henry Grattan, first sat in the Irish Parliament as one of the members of the borough. Later on Francis Dobbs, better known as " Mil lenium Dobbs", was one of its representatives, in which he was joined by a young barrister who was to achieve fame as an orator second only to Grattan himself. This unknown barrister was afterwards known as Lord Plunkett, name that still lives amongst, us, and is making Irish history to-day. Fain would we linger around Charlemont with its many historic associations and memories, but tireless as time itself the river flows ever onward to Lough Neagh. 'There before us lies Coney Island, erstwhile the secure stronghold of Shane the Proud, while the blue hills of Antrim rise dim beyond the distant shore, and in front stretching as far as eye can reach lies tho great legend-haunted lake, the grandest sheet of water in the British Isles. Here we part from the river by whose banks we have wandered, as we listened to its mystic song; here we bil adieu to the lake by whose shore we have stood watching its wavelets ripple in the sunshine. The Firbolg and Milesian, the Dane, and the Saxon have trod its banks or sailed upon its waters, but races and dynasties may pass, customs and manners change, yet lake and river remain the same, as their ripple answers to the breeze's caress, or in placid stillness mirror the fleecy clouds and blue expanse, making a mimic heaven in the carth below.

\section{IRISH INIUUSTRIES}

CORSET-MAKING.

Between forty and fifty years ago Irish corset making was a great industry. It died-how and why we cannot tell but are glad to say it is reviving again, and on a large and roost promising scale. A. Clark and Co., Henry street, Dublin are manufacturing not only for Ireland, but for the world; and last week, as we have been just informed, after competi tion, secured a great order from Melbourne, and expect this week to secure another from Bombay.

We are always glad to publish good news such as this.-Ed.

\section{MAN AND THE EARTH.}

This will have to remain over till next week. Fortunate'y neither of them are likely to run away.-ED.
Classic Idyluic?

A mảitinin ởilir, cabalp mé féın oó, oo ;

Cetó tú férn as rapparó na oépice, 'r ná इab riap no aniạ̣ oom' élliom

$\mathrm{O}$ sweet little mother give my own self to him

Give him the cows and the sheep altogether.

Go out yourself, begging alms,

And don't go west or east in search of me.

$$
\begin{aligned}
& \text { IMMORTAL. }
\end{aligned}
$$

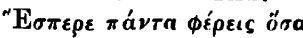

$$
\begin{aligned}
& \phi \dot{a} u r o \lambda_{e s} \tilde{\varepsilon} \sigma k a \delta \varepsilon \sigma^{*} \mathrm{~A} \omega \mathrm{s} \text {. }
\end{aligned}
$$

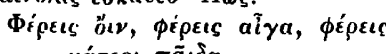

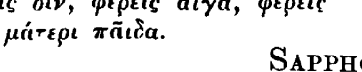

O Evening Star, thou bringest (home) all those things that the shining Dawn has scattered; home the sheep, and home the goat, and home the boy to his mother.

[But it is lovelier far in the original not only on account of the beauty and melody of the words, but because in it the Evening Star and the Dawn are is hardly even suggested by the English words.

I hope the accents are right. I shook hem out as from a pepper-castor. rankly I never could understand my self the importance of the accents. I upon the accuracy of his Greek accents, who replied, honestly enough, that he had looked them up in his Lexicon. I oo, have a Lexicon; if I could only find it.-ED.]

\section{THE POSSIBILITIES OF AGRI- CULTURE}

\section{By P. Propot kin.}

THE industrial and commercial history of the world during the last thirty years has been a history of decentralisation of industry. It was not of commerting of the centre of nessed in the past, when the commercial hegemony migrated from Italy to Spain, to Holland, and finally to ing, as it excluded the very possibility of commercial or industrial hegemony. It has shown the growth of quite new conditions, and new conditions require vive the past would be useless; a new departure must be taken by civilized ations.

Of course there will be plenty of voices to argue that the former supremacy of the pioneers must be maintained at any price: all pioneers are in the habit of saying so. It will be suggested that the pioneers must attain such a superiority of technical knowledge and organization as to enable them to beat all their younger competitors; that force must be resorted to if necessary. But force is reciprocal; and if the god of war always sides with the strongest battalions, those battalions are strongest which fight for new rights against outgrown privileges. As to the honest ging for more technical educationlet us have as much of it as possible; it will be a boon for humanity, Cabaip na bat a'r na caoin's Sंo lé1p Britain; it had a much deeper meannew adaptations. To endeavour to re-

for humanity, of course-not for a single nation, because knowledge cannot be cultivated for home use only. Knowledge and invention, boldness of thought and enterprise, conquests of genius and improvements of social organisation have become international growths; and no kind of progressintellectual, industrial or social-can be kept within political boundaries; it crosses the seas, it pierces the mountains: steppes are no obstacle to it. Knowledge and inventive powers are now so thoroughly international that if a single newspaper paragraph announces to-morrow that the problem of storing force, of printing without inking, or of aerial navigation, has received practical solution in one country of the world, we may feel sure that within a few weeks the same problem will be solved, almost in the same way, by several inventors of different nationalities. Continually we learn that the same scientific discovery, or technical invention, has been made within a fow days' distance, in countries a thousand miles apart; as if there were a kind of atmosphere which favours the germination of a given idea at a given moment. And such an atmosphere exists: steam, print and the common stock of knowledge have created it.

Those who dream of monopolising technical genius are therefore fifty years behind the times. The worldthe wide, wide world-is now the true domain of knowledge; and if each nation displays some special capacities in some special branch, the various capacities of different nations compen. sate one another, and the advantages which could be derived from them would be only temporary. The fine British wormanship in mechanical arts, the American boldness for gigantic en. terprise, the French systematic mind, and the German pedagogy, are becom. ing international capacities. Sir Wil." liain Armstrong in his Italian and Japanese workshops communicates to Italians and Japanese those capacities for managing huge iron masses which have been nurtured on the Tyne; the uproarious American spirit of enterprise pervades the Old World; the French taste for harmony becomes European taste; the German pedagogy - im. proved, I dare say - is at home in Russia. So, instead of trying to keep life in the old channels, it would be better to see what the new conditions are, what duties they impose on our genera"

(To be continued.)

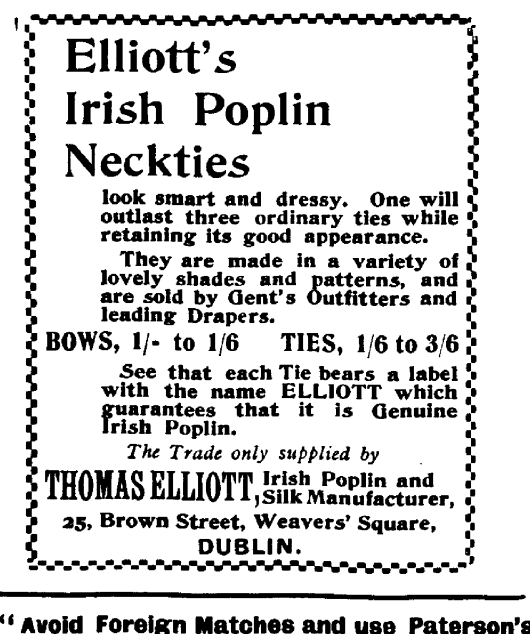

"Avoid Foreign Matches and use Paterson's "Avoid Foreign Matches and use Pa"
Irish Matohes. Mone better made." 